In some instances the capsule may be fragile and the forceps, even with the gentlest handling, are liable to tear the capsule, whereas with the suction cup method a firm hold can be obtained without risk of rupture.

In the suction cup-forceps combined method the separation of the lens from the zonule is done by the suction cup. When the lens is loose, the suction cup is removed, and the extraction is completed by forceps and squint hook.

Whether this combined method is the cataract operation of the future, only clinical experience will decide.

\title{
REFERENCES
}

BLAAUW (1941).-Arch. of Ophthal., Vol. XXV, p. 12.

DIMITRY, T. J. (1939).-Amer. Jl. Ophthal., Vol. XXII, p. 416.

DUKE-ELDER, S.-Text-book of Ophthalmology, Vol. I.

EISLER, P. (1931).-Kurzes Handbuch d. Ophthal., Vol. I.

RötTh, A. and KLEIN, M. (1930).-Klin. Monatsbl.f. Augenheilk., Vol. LXXXIV. p. 823.

DE Saint MaRTin, R. (1940).-Modern Trends in Ophthalmology.

WolfF, E (1940).-Anatomy of the Eye and Orbit.

\section{A CASE OF CONJUNCTIVAL IMPLANTATION CYST FOLLOWING OPERATION FOR DETACHMENT OF RETINA}

BY

\author{
J. R. Ascott, M.B., B.S. \\ M.o., QUEEN MARY'S HOSPITAL, ROEHAMPTON
}

History.-Male. Age 33 years. November 12, 1940, knocked down by a lorry, unconscious for a few minutes, no immediate ocular symptoms.

About four days later noticed a grey haze over the right eye; this gradually became worse until at times the eye was practically blind.

About four weeks after the accident he reported sick, and detachment of the retina was diagnosed.

December 23, 1940, operation for detachment of retina. No improvement of vision followed. About three months later his wife noticed a swelling under the R. lower lid, and this slowly increased in size during the next few months, not producing any symptoms.

Condition on examination.-August 29, 1941. R.V.: P.L. with -7.0 D. sph. H.M. at 3 metres in lower field. L.V.: $6 / 18$ with $-1 \cdot 25$ D. sph. $6 / 6$. 
In the middle of the right lower fornix there was a cystic swelling under the conjunctiva, containing clear fluid with a deposit of opaque yellow material at the bottom. The cyst measured approximately $5 / 16$ in. horizontally and $3 / 16$ in. vertically, and projected sufficiently to cause a definite fullness of the right lower lid.

The right fundus was clearly seen. The retina was in situ throughout except for a narrow zone of doubtful detachment adjacent to the atrophic scar over the area of diathermic application at the periphery below. A slightly pigmented curved line passing from the disc, horizontally, above the macula, probably indicated the " high water mark" of the old detachment. Macular degeneration had probably followed the detachment.

Operation.-October 10, 1941. Local anaesthesia. The conjunctiva covering the cyst, with the exception of a small adherent area, was reflected downwards as a flap, and the cyst gently freed by blunt dissection. It was found to be slightly adherent to the sclera from which it was freed by sharp dissection, during which it was punctured. After removal of the cyst, the deepest part of which extended to the insertion of the inferior rectus, an unabsorbable suture was found in this region and was removed. The conjunctival flap was sutured in position.

Pathological Report.-The section shows conjunctival epithelium ; beneath this, surrounded by fibrous tissue, is the implantation cyst, lined with epithelium similar to that of the conjunctiva. The

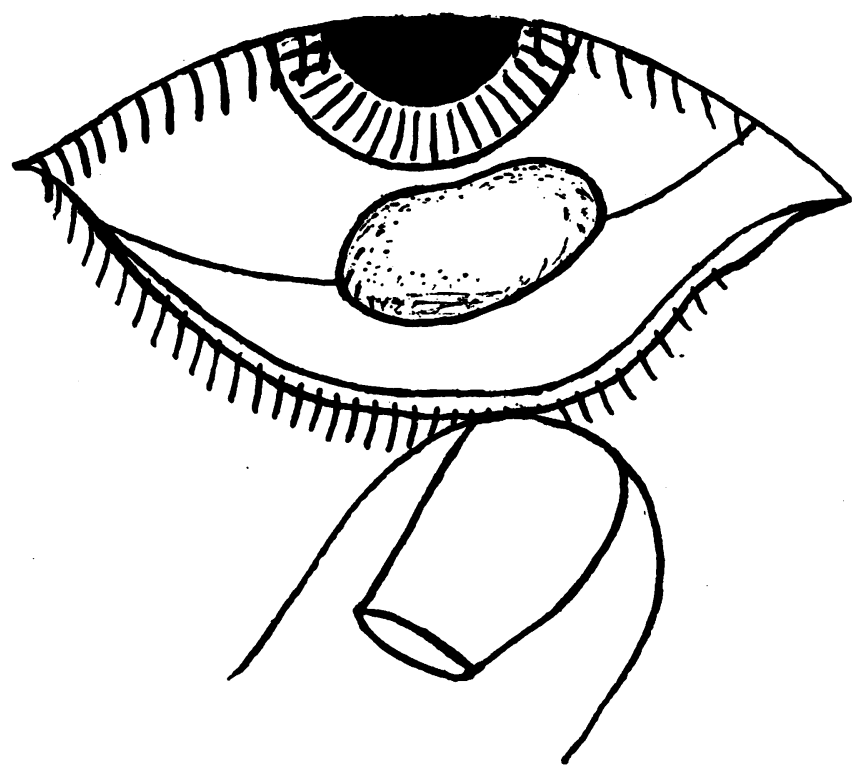

Lower lid everted, showing cyst in lower fornix. 
contents consist of red cells, a few scattered nucleated cells, and material retaining only the ghostlike form of cells.

Conjunctival implantation cysts are comparatively rare. Although in this case the cyst was found in the region of a rectus tendon suture, it is thought to be unconnected with this; the implantation of conjunctival epithelium probably occurred while a conjunctival suture was being drawn from without inwards. As a suture is being drawn through, the conjunctiva tends to drag unless it is steadied, and it is suggested that it should be held near to the entrance of the suture, and kept on the stretch, to obviate this drag as much as possible.

I am indebted to Mr. Humphrey Neame, under whose care the case was admitted, for help with this report, and to the Director General of Medical Services, Ministry of Pensions, for permission to publish it.

\section{THE DIAGNOSTIC SIGNIFICANCE OF RETRO-BULBAR NEURITIS}

BY

\section{ROSA FORD}

LONDON

A CASE of retro-bulbar neuritis always arouses in our minds the query " does this signify the onset of disseminated sclerosis?", for a good proportion of cases are followed by this dread disease.

In the case here described, it was the precursor, not of disseminated sclerosis, but of two other diseases, viz. iritis and rheumatoid arthritis.

F.T., a woman aged 20 years, was attacked by retro-bulbar neuritis in 1923. As happens in an unpleasantly large percentage of cases, all search for a cause proved fruitless, but she recovered spontaneously in 7 weeks. Three years later she began to suffer from rheumatoid arthritis and the next year from iritis. When first seen by me in 1931 for her third attack of iritis, the arthritis had advanced to marked deformities, and for the last 5 months the acute pain in her joints had confined her to bed.

F.T. had thus been the victim of 3 successive diseases, retrobulbar neuritis, arthritis and iritis, to none of which had it been possible to ascribe any cause. They are in fact 3 of our medical problems.

On the supposition that a septic focus might exist in the sinuses, in spite of the absence of nasal signs or symptoms, an attempt was made to drain them. By the application of argyrol and 